Uluslararası Mühendislik

Cilt/Volume:11 Sayı/Issue:2 Haziran/June 2019

Araştırma Makalesi / Research Article

\title{
Investigation of Sintering Behaviour of Bone China Bodies Produced by Bone China Wastes
}

\author{
Fazilet Güngör *1 iD \\ ${ }^{1}$ Kütahya Porselen, R\&D Center, Atatürk Bulv. 8. Km., Kütahya, TURKEY
}

Başvuru/Received: 08/11/2018

Kabul/Accepted: 14/05/2019

Son Versiyon/Final Version: 30/06/2019

\begin{abstract}
Flawed and broken wastes obtained from the production of Bone China were used for formulating Bone China body recipe instead of albite, quartz and bone ash as the same chemical composition of original Bone China body. The amount of kaolin and clay were used as the same amount of the Bone China body due to obtain optimum plastic behaviour. This study was carried out in two steps. At the first step, compositions were fired at the original firing temperature of Bone China as $1250{ }^{\circ} \mathrm{C}$ and at the second step, compositions were fired at $1200{ }^{\circ} \mathrm{C}$. Water absorption and pyroplastic deformation results of the bodies were measured. XRD and SEM determined the phase and microstructural evaluation of the bodies, respectively. As the amount of the Bone China waste increased amount of the glassy phase increased, anorthite and quartz were decreased. Technical properties of the bodies changed parallel to the microstructural changes. As the amount of bone waste increased in the compositions, optimum technical properties of the compositions were obtained at $1200^{\circ} \mathrm{C}$.
\end{abstract}

Key Words

"Bone China, Bone ash, Bone China waste, Microstructure, Sintering" 


\section{Introduction}

As a ceramic material, Bone China is a highly specialized product and is the basis of the word's most attractive and expensive types of tablewares, mainly due to its translucency, whiteness, bright glaze, decoration quality and high strength (Kara \& Stevens, 2002). It was first developed and and commercially sold by Josiah Spode II in Stoke on Trend at 1794 A.D. (Rado, 1981).

Dodd (1964) has defined Bone China as a vitreous translucent pottery made from a body of the following approx. composition (Dodd, 1964),

Calcined Bone: $45-50 \%$

China Clay: : $: 25-30 \%$

Cornish Stone : $25-30 \%$

The overall microstructure of Bone China lies in the eutectic region of $11 \%$ tricalcium phosphate, $38 \%$ silica and $51 \%$ anorthite with a melting temperature of $1290+/-5^{\circ} \mathrm{C}$. If the firing proceeds slowly at temperature just above $1250{ }^{\circ} \mathrm{C}$, the deformation parts may occur. Therefore, the firing should be conducted in nonequilibrium conditions, forming the fired phases that are anorthite, $\beta$ Calcium tri phosphate and a siliceous glass (Carus et al., 2012, .Iqbal et al, 2000; Douglas et al, 2015)

The main role of bone ash is to form crystalline phases and its main constituent is hydroxyapatite $\left(\mathrm{Ca}(\mathrm{OH})_{2} \cdot 3 \mathrm{Ca} 3(\mathrm{PO})_{2}\right)$, which decomposes forming calcium oxide $(\mathrm{CaO})$ and $\beta$-tricalcium-phospate $\left(\beta-\mathrm{Ca}_{3}\left(\mathrm{PO}_{4}\right)_{2}\right)$, according to the following reaction:

$\mathrm{Ca}(\mathrm{OH})_{2} \cdot 3 \mathrm{Ca}_{3}\left(\mathrm{PO}_{4}\right)_{2} \longrightarrow \mathrm{CaO}+\mathrm{H}_{2} \mathrm{O}+3 \mathrm{~B}-\mathrm{Ca}_{3}\left(\mathrm{PO}_{4}\right)_{2}$

Lime released during the process rapidly reacts with dehydrated kaolinite $(\mathrm{Al} 2 \mathrm{O} 3.2 \mathrm{SiO} 2)$, forming anorthite $\left(\mathrm{CaO}^{\mathrm{A}} \mathrm{Al}_{2} \mathrm{O}_{3} .2 \mathrm{SiO}_{2}\right)$ (Bragança \& Bergman, 2008):

$\mathrm{CaO}+\mathrm{Al}_{2} \mathrm{O}_{3} \cdot 2 \mathrm{SiO}_{2} \longrightarrow \mathrm{CaO} \cdot \mathrm{Al}_{2} \mathrm{O}_{3} \cdot 2 \mathrm{SiO}_{2}$

Bone ash or calcined bone in the manufacturing of Bone China, making Bone China generally more durable and translucent than kaolin based porcelain but one of the most expensive raw material for tableware industry (Douglas et al., 2015, Batista\&Hand, 2001). Therefore it is the one of the important parameter for determining the cost of the Bone China ware. On the other hand, it is important to remark that calcination and cleaning of bones can cause some pollution; mainly regarding burning of combustible gases. Therefore, not only because of its high price but also because of its environmental effects, utilization of Bone China wastes is important for tableware industry.

Several authors have recently investigated the microstructural development of Bone China body (Kara, 2004; Kara \& Stevens , 2002) but the effect of Bone China waste on the sintering behavior of Bone China body has not been studied. In this study, effect of Bone China wastes on the sintering behavior of Bone China production was investigated.

\section{Experimental Procedure}

Bone waste was washed with distilled water and grinded by jet mill (Ceramic instruments). The particle size of the grinded Bone China waste and the other unplastic raw materials (bone ash, quartz and albite) were measured by laser diffraction method using Malvern Master Sizer 200 G model and the results were given in Table 1. Chemical compositions of Bone China, bone ash, quartz, albite, kaolin and clay were given in Table 2. Bone China wastes were used in the Bone China recipe instead of albite, quartz and bone ash as BA05: $\%$, BA10:10\%, BA15:15\% and BA20:20\%. The recipes were designed to obtain the chemical analysis of the basic Bone China recipe without waste (BA00).

To prepare the batches, raw materials were dispersed in an aqueous slip containing $70 \mathrm{wt}$. percentage solid and $0.01 \mathrm{wt}$. percentage dispersant (Na-silicate). After then, mixed for $1 \mathrm{~h}$ using IKA RW 20 digital mixer. The slurries were screened with 60 mesh $(250$ $\mu \mathrm{m})$ sieves. Slips were poured into the bar shaped plaster moulds for pyroplastic deformation measurement. Samples were fired at the firing cycles as given in Fig. 1. Dimensions of the bars were $3.5 \mathrm{~cm}$ x $20 \mathrm{~cm} \mathrm{x} 1 \mathrm{~cm}$. Water absorption values were determined by water saturation and Archimedes principle (ISO 10545-3).

The pyroplastic index (PI) of each samples were determined by three point test method after firing: where $\mathrm{h}$ is the thickness of the body, $\mathrm{S}$ the maximum deflection and $\mathrm{L}$ the distance between the refractory supports as indicated in Fig. 2 (Conserva et al., 2017).

$P I=4 h^{2} / 3 L^{4} S$

The detection of the phases formed in the fired products was performed with a Rigaku Rint 2000 X-ray diffraction device. A full profile interpretation by Rietvelt refinement was carried out with the GSAS-EXP GUI software package. In addition, for microstructural examinations, secondary electron images were taken with scanning electron microscopy (SEM, Zeiss Supra 50 VP) at the fractured surfaces of the samples leached with $10 \%$ diluted HF. Light transmission of the fired samples were measured by TES 1332-lux meter according to TS EN 1184. 


\section{Results And Discussion}

XRD patterns of the samples of BA00 and BA20 fired at HT01 were given in Fig. 3 and obtained quantification of crystalline and glassy phases by Rietvelt refinement of the XRD patterns were given in Fig. 4.

The phases obtained in the sample of BA00 (also Bone China) were; anorthite, cristobalite, quartz and glassy phase. Bone China bodies have high light transmission because the refractive index of the anorthite phase is close to the glassy phase (glass phase:1.5 and anorthite:1,58) (Güngör, 2018). Despite the same chemical composition of the whole bodies, the reason of the decrease of anorthite phase is the formation of glassy phase was increased as the amount of waste increased in the body composition. "The anorthite phase" from Bone China waste dissolved in the glassy phase and therefore the amount of anorthite in the composition decreased.

The total amount of quartz and cristoballite were decreased as the amount of waste increased in the compositions. Because of the increased amount of the glassy phase formation, quartz and cristobalite dissolved in the glassy phase. Cristobalite is a high temperature silica polymorph being stable in the temperature range of $1470-1705^{\circ} \mathrm{C}$, but also occurs out of its stability field as a metastable phase. Cristobalite also develops at $\mathrm{T} \leq 1000{ }^{\circ} \mathrm{C}$ from $\mathrm{SiO}_{2}$ glass. Upon cooling, $\beta$-cristoballite turns into its tetragonal $\alpha$ phase at $270{ }^{\circ} \mathrm{C}$, not being able to overcome the activation energy barrier to change into the stable silica phase (Pagliari et al.., 2013)

Despite the absence of aluminium phosphate in the microstructure of Bone China body, aluminium phosphate started to form when the waste was added into the Bone China body composition. The amount of aluminium phosphate was increased as the amount of waste increased. Aluminium phosphate formed as a result of the reaction of $\mathrm{PO}_{4}$ and alumina released from anortite crystals dissolved from waste.

The water absorption (WA) results of the sintered samples are shown in Fig 5. Water absorption of the samples were decreased as the amount of waste in the composition was increased. This result showed that by introducing Bone China waste, a notable reduction in the sintering temperature occurred. As the amount of liquid phase in the microstructure increases, gaps between the grains are filled with the liquid phase and the density of the sample increases. The amount and viscosity of the glassy phase is a determiner for the rate of sintering. Decreased viscosity of the glassy phase increases the sintering rate of the polycrystalline ceramic (Lerdprom, 2014; Güngör \& Ay, 2018). The viscosity of the glassy phases formed in the samples were determined according to Lakatos et al (1972) and the results were given in Fig. 6.

The viscosity of the glassy phases increased as the amount of Bone China waste increased. The reason of the increased sintering rate was the increased amount of glassy phase. The viscosity of the glassy phases were increased because of the increased dissolution of quartz as the amount of waste increased. The viscosity-temperature relationship of the glasses depends on the displacement behaviour of cations with silica (Hülsenberg a.o., 2008).

The pyroplastic deformation results of the samples fired HT001 were given in Table 3. The pyroplastic deformation behaviour of the samples were increased as the amount of glassy phase in the microstructure of the samples increased. Because of the increased amount of the glassy phase, slippage tendency of the grains increased at the maximum temperature of firing process and as a result of increased slippage tendency pyroplastic deformation increased. Backscattered electron (BSE) images of the fractured surfaces of the specimens produced after firing at HT01 are given in Fig. 7.The main phase of the microstructures for the samples of B A00 and BA20 was anorthite. The another phase that determined for BA20 was aluminium phosphate also determined by XRD analysis.

According to the experimental results, samples fired at $1250{ }^{\circ} \mathrm{C}$, sintering rate was increased as a result of increased waste in the compositions. According to these results, in order to save energy by reducing the firing temperature of the samples, the sintering rate of the samples were examined by firing at lower temperature than the first step of the study as shown in Fig. 1. The water absorption and pyroplastic deformation results of the samples were given in Table 4. The water absorption of the samples were decreased and the pyroplastic deformation of the samples were increased as the amount of waste increased. When the results of water absorption and pyroplastic deformation index results of the sample of BA20 fired at HT02 were compared with the Bone China (BA00) which was fired at HT01, the water absorption and pyroplastic deformation values are similar.

Rietvelt analysis results of the samples fired at HT02 were given in Fig. 8. When the phase contents of the bodies are examined in comparison with the waste excluded Bone China, the samples containing $20 \%$ of the waste fired at $1200{ }^{\circ} \mathrm{C}$ have similar phases and ratios with the waste excluded sample which was fired at $1250{ }^{\circ} \mathrm{C}$.

\section{Conclusion}

Bone China waste bodies when fired at the Bone China firing cycle $\left(1250^{\circ} \mathrm{C}\right)$ had higher amount of glassy phase and lower amount of crystalline phases. As a result of dissolution of Bone China waste, amount of glassy phase increased.

This change in the microstructure decreased the water absorption value but increased the value of pyroplastic deformation. When the firing temperature was lowered to $1200{ }^{\circ} \mathrm{C}$, samples with Bone China waste and the original Bone China fired at $1250{ }^{\circ} \mathrm{C}$ had similar water absorption values and also similar values were obtained for pyroplastic deformation. The reduction of firing 
temperature obtained for Bone China waste bodies is explained by the microstructural evoluation of the samples. Because nearly the same microstructure was obtained by the samples with Bone China waste.

\section{Tables}

Table 1. Particle size analysis results of the raw materials.

\begin{tabular}{cccc}
\hline & $\begin{array}{c}\mathbf{d}(\mathbf{0 , 1}) \\
\boldsymbol{\mu m}\end{array}$ & $\begin{array}{c}\mathbf{d}(\mathbf{0 , 5}) \\
\boldsymbol{\mu m}\end{array}$ & $\begin{array}{c}\mathbf{d}(\mathbf{0 , 9}) \\
\boldsymbol{\mu m}\end{array}$ \\
\hline Quartz & 4.5 & 21.1 & 65.2 \\
Albite & 4.9 & 24.3 & 72.1 \\
Bone Ash & 5.3 & 22.5 & 72.5 \\
Bone & 7.4 & 29.15 & 81.52 \\
Waste & & \\
\hline
\end{tabular}

Table 2. Chemical composition results of the raw materials.

\begin{tabular}{cccccccccccc}
\hline & $\mathrm{SiO}_{2}$ & $\mathrm{Al}_{2} \mathrm{O}_{3}$ & $\mathbf{C a O}$ & $\mathbf{M g O}$ & $\mathbf{K}_{2} \mathbf{O}$ & $\mathbf{N a}_{2} \mathrm{O}$ & $\mathbf{F e}_{2} \mathrm{O}_{3}$ & $\mathbf{T i O}_{2}$ & $\mathbf{P}_{2} \mathrm{O}_{5}$ & $\mathbf{L O I}$ & Total \\
\hline BA00 & 51.96 & 12.11 & 18.7 & 1.8 & 0.72 & 0.01 & 0.01 & 0.01 & 10.78 & 3.9 & 100 \\
Quarz & 99.63 & 0.11 & 0.01 & 0.01 & 0.04 & 0.1 & 0.07 & 0.01 & 0.02 & - & 100 \\
Albite & 69.31 & 20.5 & 0.1 & 0.1 & 0.21 & 9.57 & 0.1 & 0.1 & 0.01 & - & 100 \\
Kaolin & 47.09 & 38.15 & 0.01 & 0.01 & 1.12 & 0.03 & 0.34 & 0.04 & 0.01 & 13.2 & 100 \\
Clay & 47.4 & 36.82 & 0.01 & 0.01 & 1.71 & 0.02 & 0.38 & 0.05 & 0.02 & 13.58 & 100 \\
Bone Ash & 0.9 & 1.9 & 50.5 & 1.4 & 1.35 & 2.15 & 0.3 & - & 37.2 & 4.3 & 100 \\
\hline
\end{tabular}

Table 3. Pyroplastic index results of the samples fired at HT01.

\begin{tabular}{cc}
\hline Sample & PI $\left(\mathbf{c m}^{-\mathbf{1}}\left(\mathbf{1 0}^{\mathbf{- 5}}\right)\right)$ \\
\hline BA00 & 7.90 \\
BA05 & 9.12 \\
BA10 & 10.24 \\
BA15 & 11.49 \\
BA20 & 12.84 \\
\hline
\end{tabular}

Table 4. Water absorption and pyroplastic index results of the samples fired at HT02.

\begin{tabular}{ccc}
\hline Sample & $\begin{array}{c}\text { Water Absorption } \\
\text { \% }\end{array}$ & PI $\left(\mathbf{c m}^{-\mathbf{1}}\left(\mathbf{1 0}^{-\mathbf{5}}\right)\right)$ \\
\hline BA00 & 2.11 & 4.70 \\
BA05 & 1.68 & 5.61 \\
BA10 & 1.32 & 6.29 \\
BA15 & 0.89 & 7.29 \\
BA20 & 0.57 & 8.11 \\
\hline
\end{tabular}


Figures

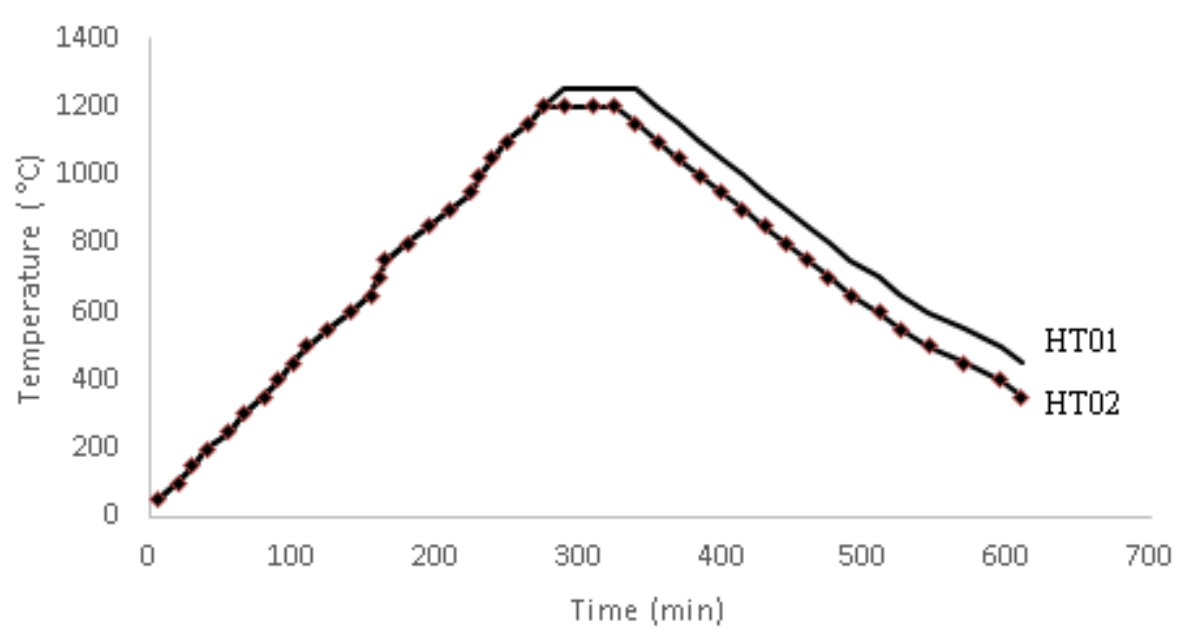

Fig 1. Firing cycles of the samples

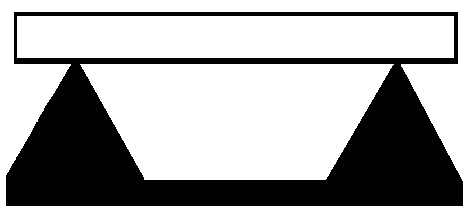

Before firing

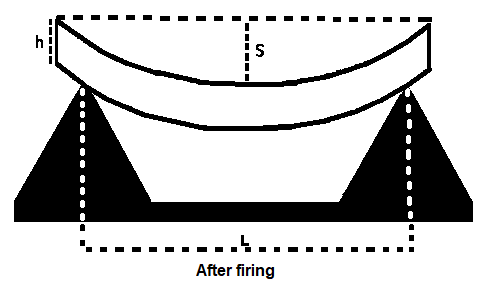

Fig.2. Positioning of the sample before and after firing for pyroplastic index assay.

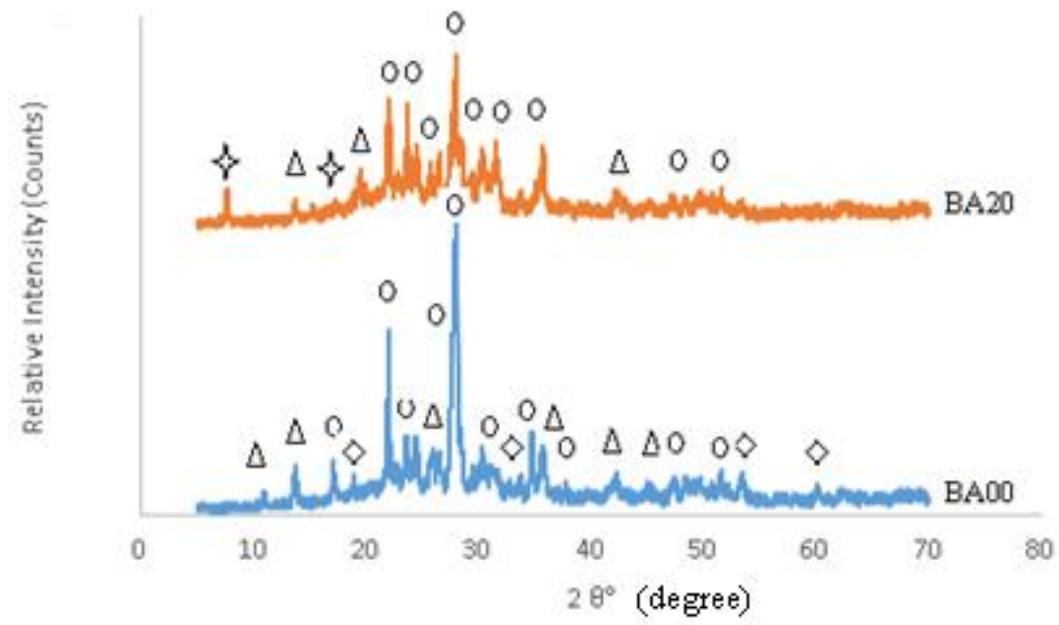

Fig 3. XRD analysis results of the samples fired at $1250^{\circ} \mathrm{C} \Delta$ : quartz, $\diamond:$ cristoballite, ${ }^{\circ}$ : anorthite, $\triangleleft$ : Aluminum Phospate. 


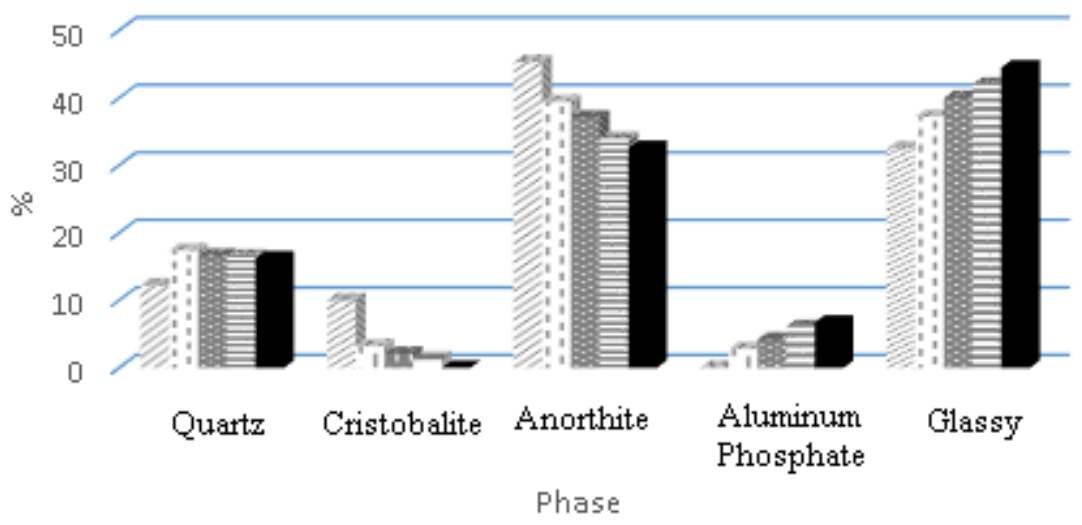

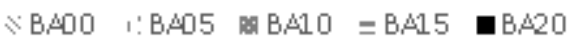

Fig 4. Rietvelt analysis results of the samples fired at HT01.

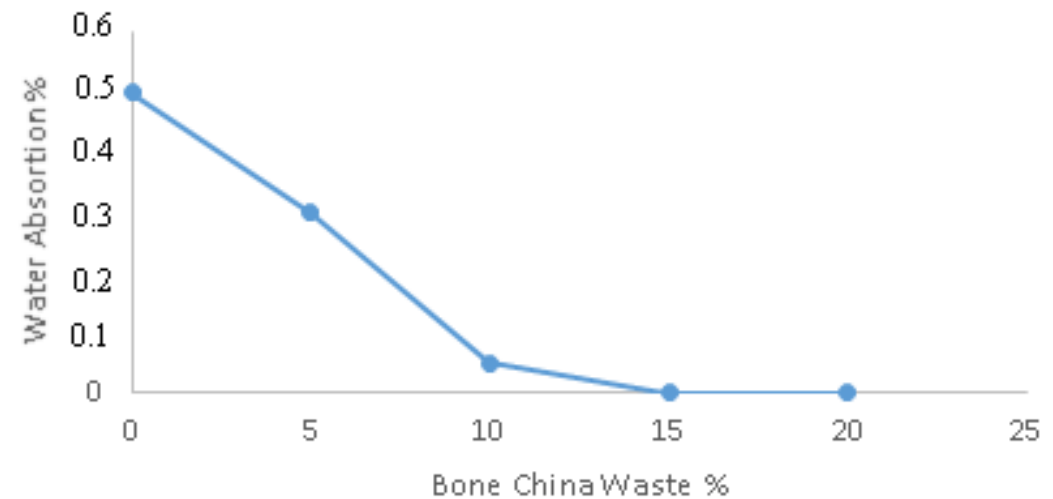

Fig. 5. Water absorption results of the samples fired at HT01.

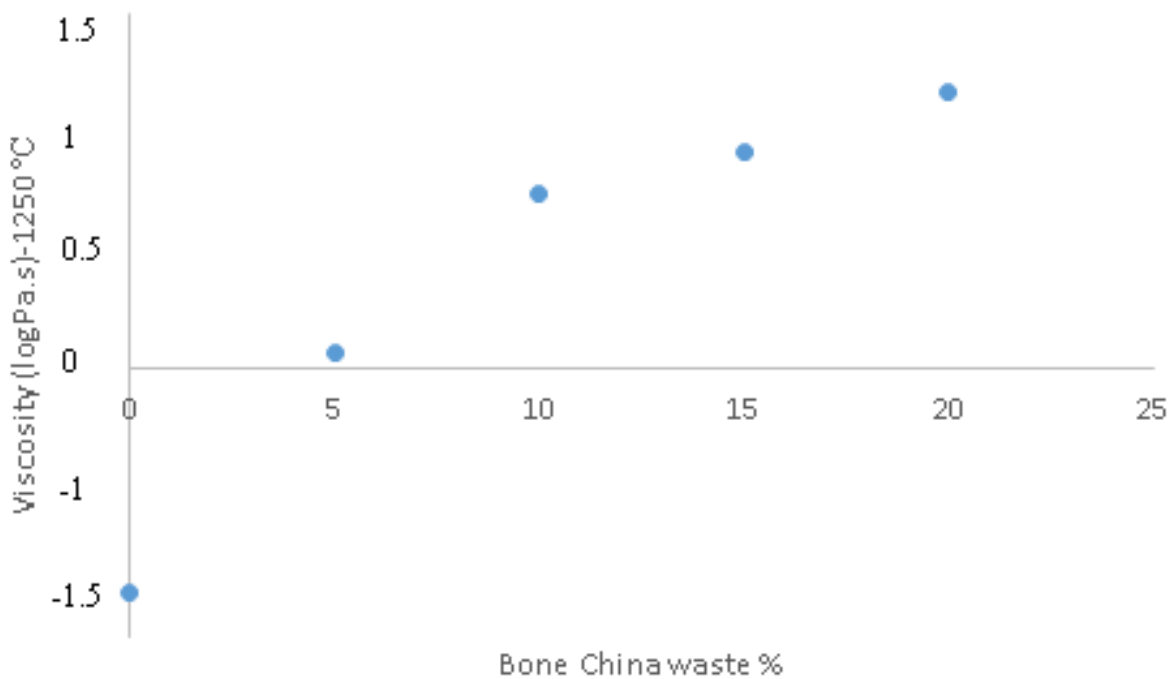

Fig. 6. Viscosity of the glassy phases of the samples fired at HT01. 


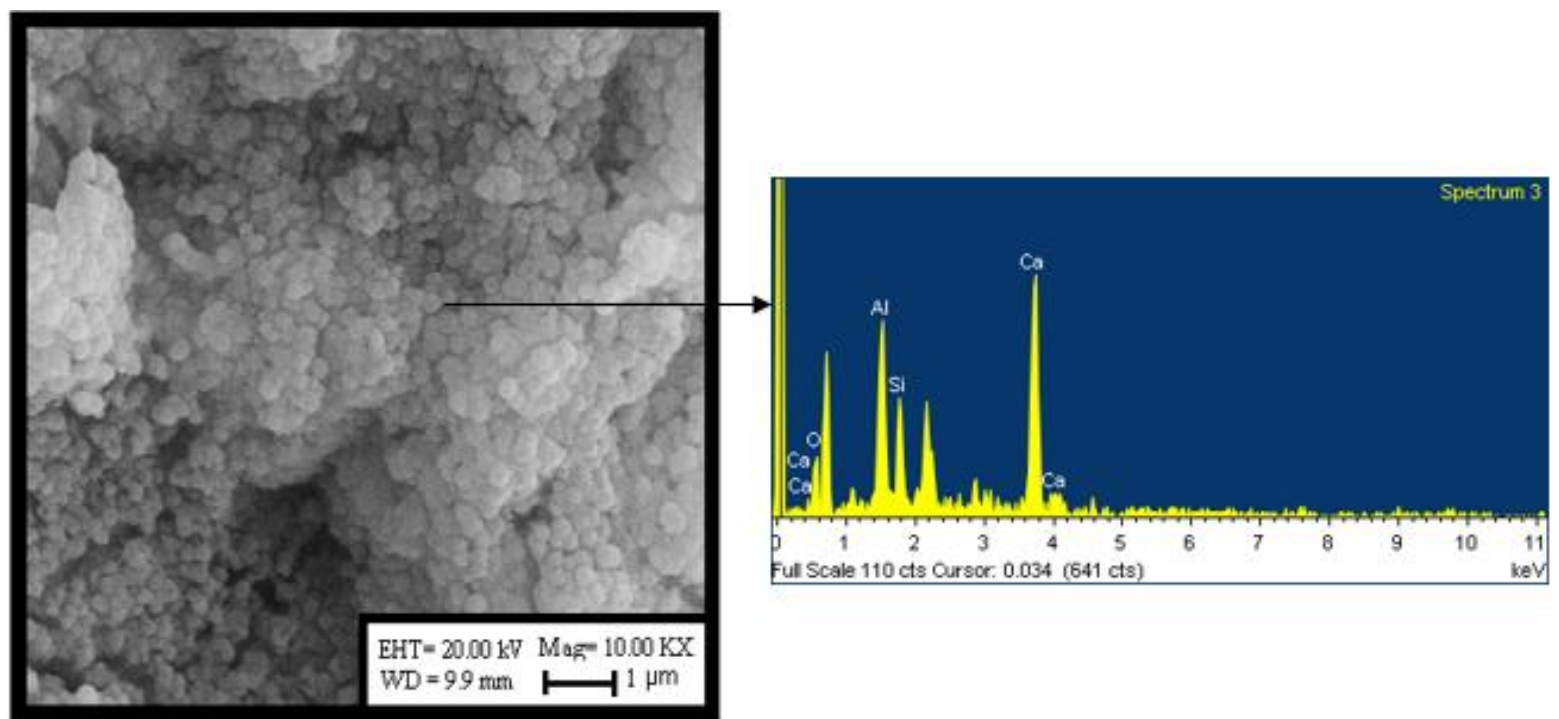

(a)

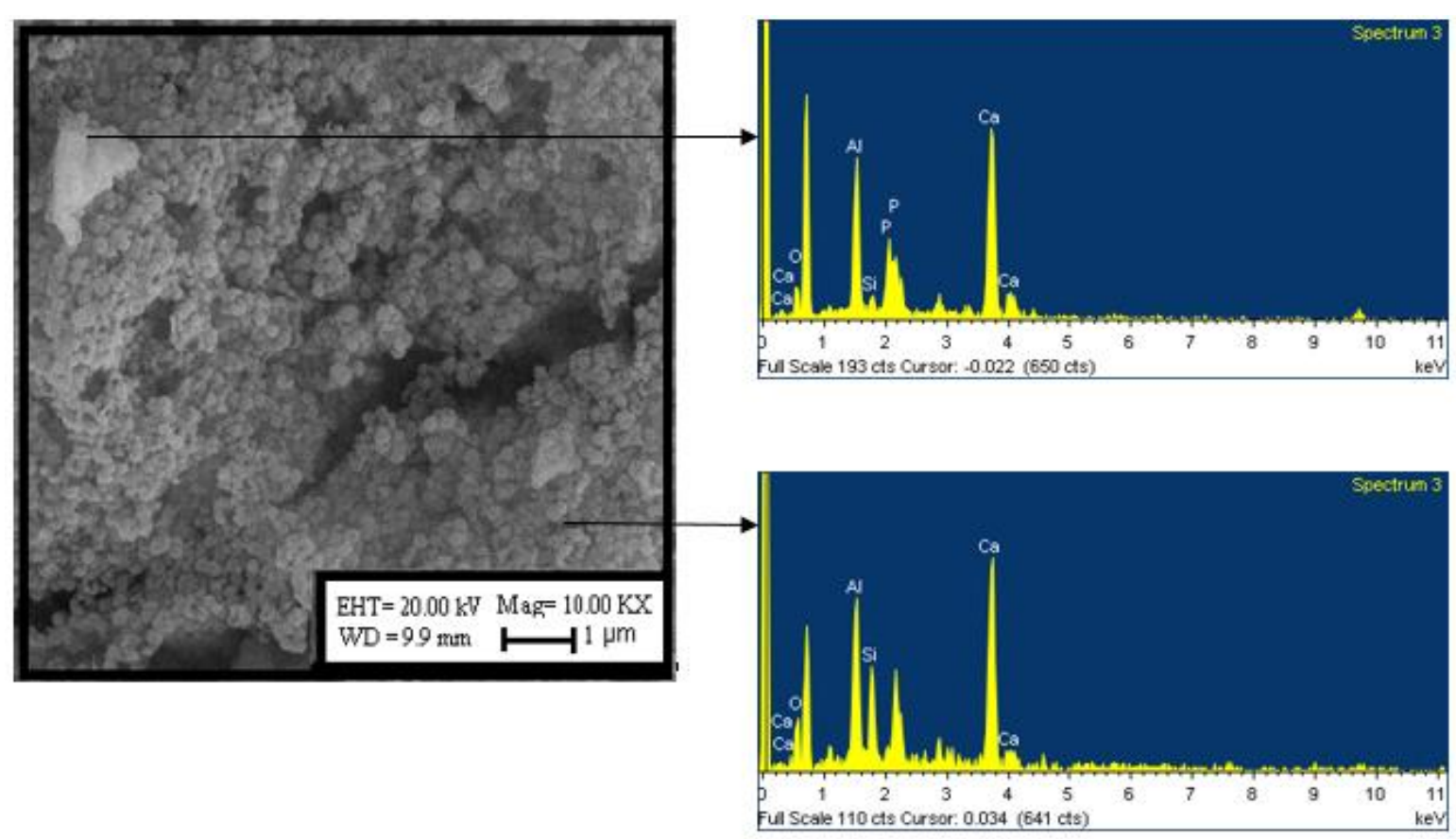

(b)

Fig. 7. SEM and EDX images of the samples fired at HT0; (a) BA00 (b) BA20

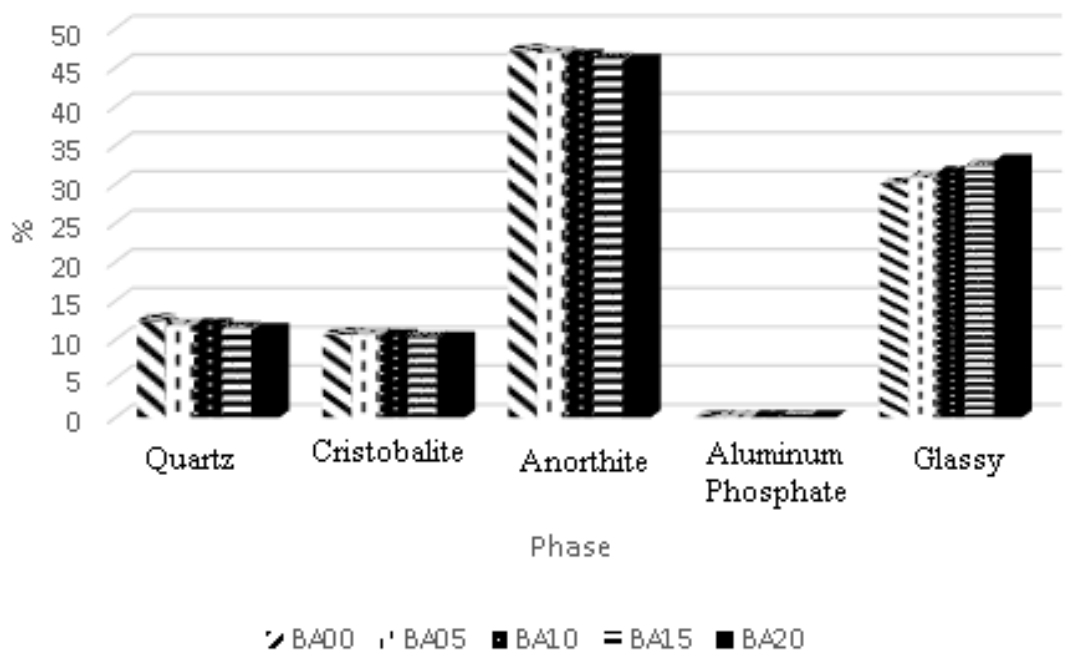

Fig 8. Rietvelt analysis results of the samples fired HT02. 


\section{References}

Batista, S.A. F.\& Hand, R.J. (2001). Fracture toughness of Bone China and hard porcelain, Br. Ceram. Trans., 100 (6), 256-259 doi: $10.1179 /$ bct.2001.100.6.256.

Bragança, S.R. \& Bergman, B.R. (2008), A comparative study between Bone China and hard porcelain. Industrial Ceramics, 28(3):189-194.

Carus, L. A., Souza, F., Bragança, S.R. (2012), Use of Wollastonite as a Flux for Bone China Bodies, Int. Scholarly Research Network, 701821.doi: 10.5402/2012/701821.

Conserva, L.R.S., Melchiades,F.G., Nastri, S., Boschi, A.O., Dondi, M., Guarini, G., Raimondo, M. (2017). Pyroplastic deformation of porcelain stoneware tiles: wet vs. dry processing, J. Eur. Ceram. Soc., 37, 333-342.

Douglas, G., Kaneko, T.T., Kahn, H., Conceiçao, E.S.\& Antoniassi, L. (2015), Using bone ash as an additive in porcelain sintering, Ceram. Int., 41, 487-496, doi: 10.1016/j.ceramint.2014.08.096.

Güngör, F. (2018). Investigation of pyroplastic deformation of whitewares: Effect of crystal phases in CaO based glassy phase. Ceram. Int., 44, 13360-13366.

Güngör, F.\& Ay, N. (2018). The effect of particle size of body components on the processing parameters of semi transparent porcelain. Ceram. Int., 44, 10611-10620.

Hülsenberg D., Harnisch A., Bismarck A. (2008), Microstructuring of Glasses, Berlin, Springer.

Iqbal, Y.,. Messer, P.F., Lee, W. E., (2000), Non equilibrium microstructure of Bone China. Br. Ceram. Trans, 99 (3), 110-116.doi: $\underline{10.1179 / 096797800680811 .}$.

Kara, A. (2004). An Investigation Into Bloating Behaviour of Bone China Body During Biscuit Firing. Key Eng. Materials, 264268. doi: 10.4028/www.scientific.net/KEM.264-268.1717

Kara, A. \& Stevens, R.(2002b). Characterisation of biscuit fired Bone China body microstructure. Part 2: Transmission electron microscopy (TEM) of glassy phase. J. Eur. Ceram. Soc., 22, 737-743.

Kara A. \& Stevens R. (2002a), Characterisation of biscuit fired Bone China body microstructure. Part 1: XRD and SEM of crystalline phases, Jour., Euro. Ceram. Soc., 22, 731-736, doi: 10.1016/S0955-2219(01)00371-5

Lakatos, T., Johansson, L. G., Simmingsköld, B. (1972). Viscosity temperature relations in the glass system $\mathrm{SiO}_{2}-\mathrm{Al}_{2} \mathrm{O}_{3}-\mathrm{Na}_{2} \mathrm{O}-$ $\mathrm{K}_{2} \mathrm{O}-\mathrm{CaO}-\mathrm{MgO}$ in the composition range of technical glasses. Glass Technology, 13,(3), 88-95.

Lerdprom, W. (2014). Firing of porcelain, Alfred University, Master of Science thesis, Alfred Universty, Alfred, Newy ork, USA.

Pagliari, L., Dapiaggi M., Pavese A., Francescon F., (2013). A kinetic study of the quartz crystobalite phase transition. J. Eur. Ceram. Soc. 33, 3403-3410.

Rado, P. (1981), Bone China, Ceramic Monographs- Handbook of Ceramics. Freiburg, MA: Verlag Schmid GmbH.

Dodd, A. E. (1964), Dictionary of ceramics, London, MA: George Newnes. 